\section{From Tragedy to}

Triumph-Resources for Rebuilding Green after Disaster

These resources offer builders and architects information about building healthier, more comfortable, and more energy-efficient homes, businesses, and public buildings.

\section{Financial Incentives}

Numerous financial incentives, such as federal and state tax credits and utility rebates, are available to help offset the cost of a renewable energy system. Many utility companies also offer net metering for renewable energy systems that are connected to the grid. And the American Recovery and Reinvestment Act, signed into law on February 17, 2009 , contains provisions that will financially benefit individuals, businesses, organizations, and the renewable energy industry as a whole.

For more information about financial incentives, visit the Database of State Incentives for Renewables and Efficiency at www.dsireusa.org.

\section{Commercial Building Energy Alliances}

Partner members of these U.S. Department of Energy (DOE) alliances help guide research and encourage industry to move toward energy-efficient design and strategies in commercial buildings

www.buildings.energy.gov/ commercial_initiative/alliances.htm/

\section{Retailer Energy Alliance} www.buildings.energy.gov/retailer/

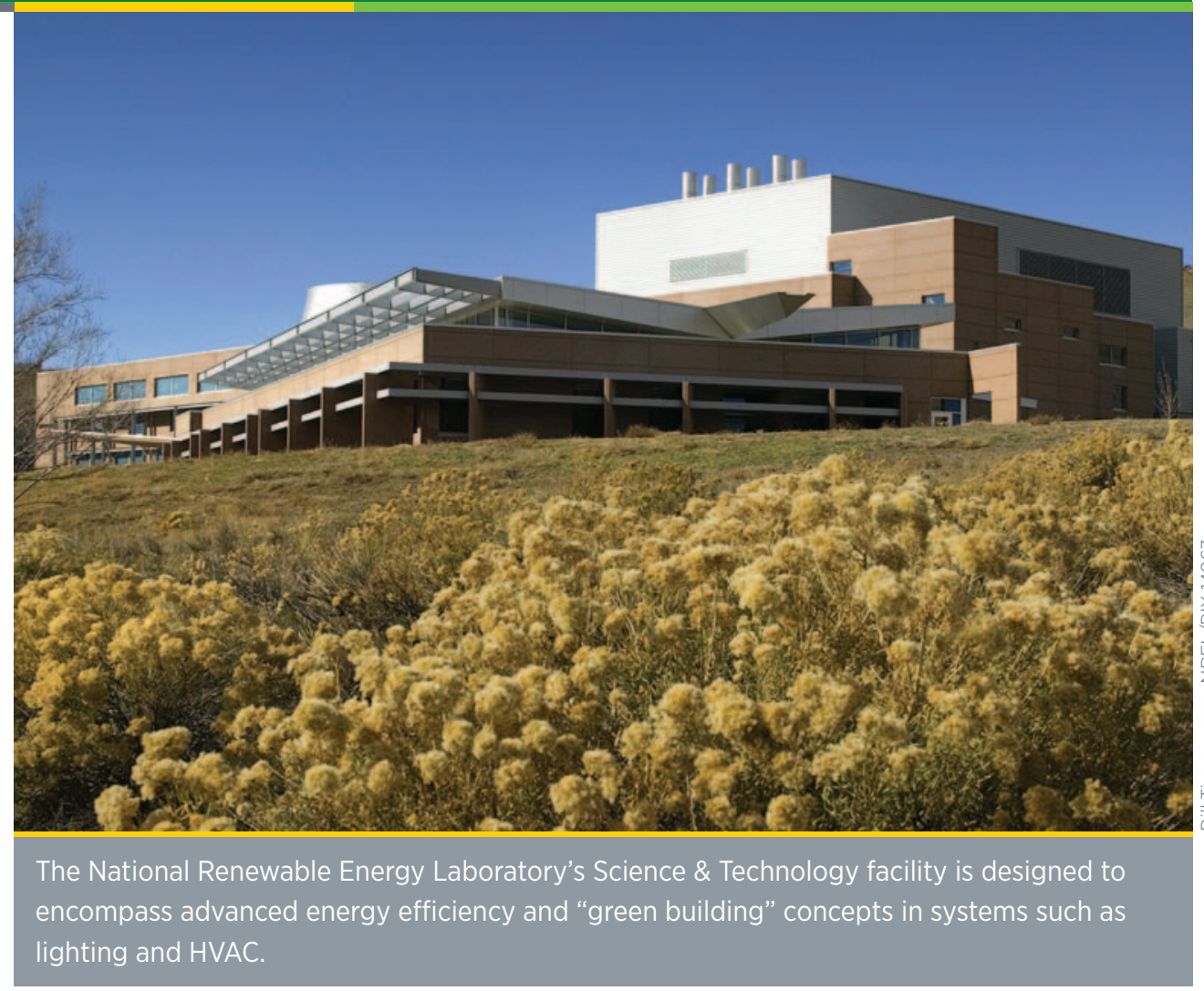

\section{Rebuilding a business or home after a natural disaster such as a flood, hurricane, or tornado can be daunting. These resources can help you turn tragedy into opportunity by rebuilding with energy efficiency and renewable energy to create healthier buildings and homes.}

\section{Hospital Energy Alliance} www.buildings.energy.gov/hospital/

\section{Commercial Real Estate Energy Alliance}

www.buildings.energy.gov/real_estate/

\section{Energy Efficiency Resources}

\section{Energy Savers}

Basic information about energy efficiency and renewable energy from DOE

www.energysavers.gov

\section{ENERGY STAR ${ }^{\circledast}$}

This program of DOE and the U.S. Environmental Protection Agency (EPA) helps building owners save energy and money through energy-efficient products and practices www.energystar.gov

\section{Commercial Buildings Energy Efficiency Practices}

Guidelines from DOE for each step of the design and building process www.buildings.energy.gov/commercial/ index.html 


\section{EnergySmart Schools}

Guidelines for building green schools from DOE

www.buildings.energy.gov/

energysmartschools

\section{Green Guides and Case Studies}

\section{Green Building}

Provides general information about green buildings along with case studies from EPA

www.epa.gov/greenbuilding/

\section{Green Building Case Studies}

A database of green commercial buildings from the U.S. Green Building Council (USGBC) www.usgbc.org/LEED/Project/ CertifiedProjectList.aspx

\section{Green Home Building Guidelines}

Guidelines for building green homes from the National Association of Homebuilders (NAHB) www.nahbgreen.org/Guidelines/ nahbguidelines.aspx

\section{Green Schools Guide}

Guidelines for building green schools from USGBC www.buildgreenschools.org/

\section{Greensburg Sustainable Buildings Database}

Case studies of green commercial buildings and homes in Greensburg, Kansas http://greensburg.buildinggreen.com

\section{High-Performance Buildings Database}

Information from DOE about more than 100 high-performance buildings http://eere.buildinggreen.com/

\section{Remodeling Green Guidelines}

A publication about remodeling an existing home to make it green www.greenhomeguide.org/documents/ regreen_guidelines.pdf

\section{Top Ten Green Buildings}

The American Institute of Architects gives annual awards for the top ten green buildings.

www.aiatopten.org/hpb/

\section{Renewable Energy Resources}

\section{A Homebuilder's Guide to Going Solar}

This publication helps builders assess the benefits of installing solar equipment or making houses "solar ready" to both their businesses and customers. www.solar.energy.gov/pdfs/44792.pdf
Own Your Power! A Consumer Guide to Solar Electricity for the Home

Information about solar energy systems, financial incentives, and warranties and insurance along with tips for success www.nrel.gov/docs/fy09osti/43844.pdf

\section{Small Wind Electric Systems}

A consumer's guide with information about small wind energy systems for rural areas, including maintenance and zoning issues www.windpoweringamerica.gov/pdfs/ small_wind/small_wind_guide.pdf

\section{Geoexchange}

A Web site from the Geothermal Heat Pump Consortium that presents information about geothermal heating and cooling www.geoexchange.org

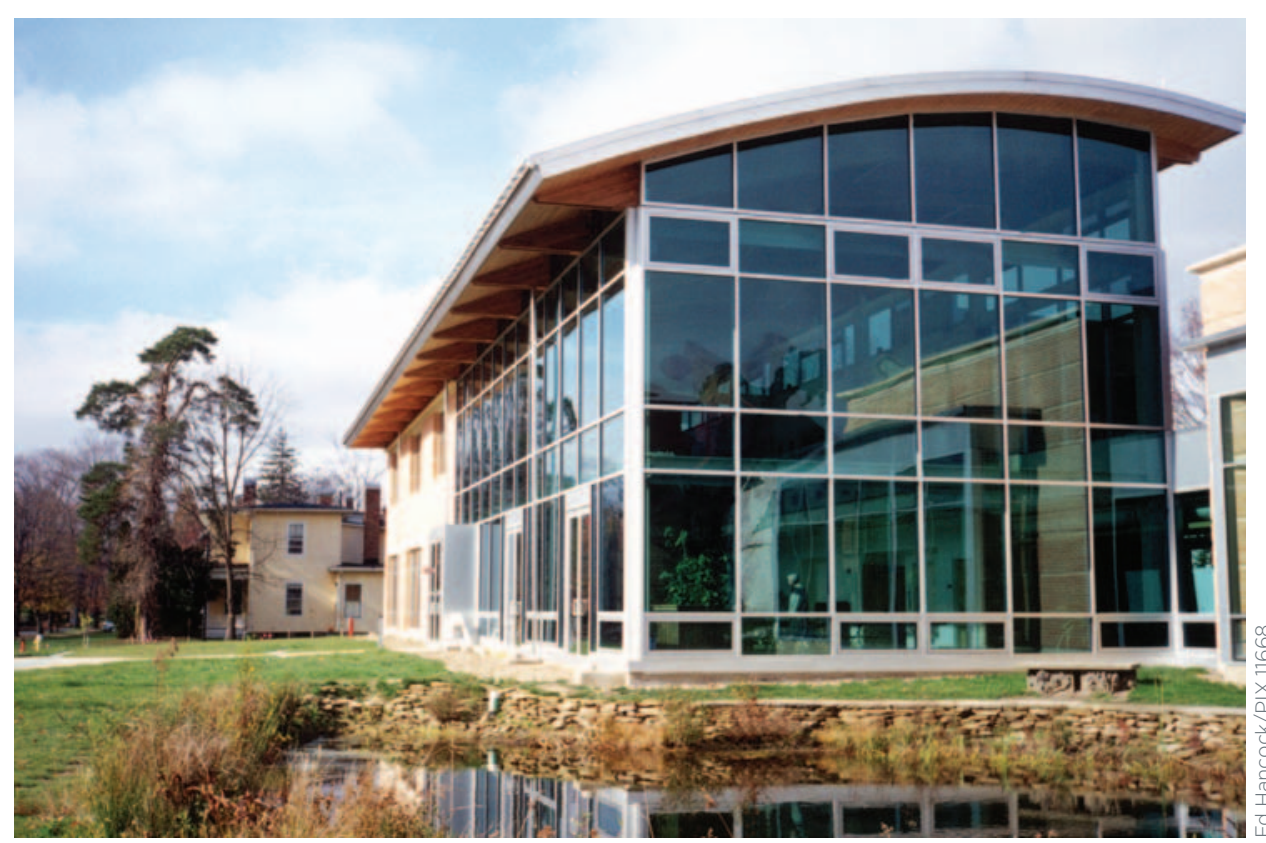

The atrium at the Adam Joseph Lewis Center for Environmental Studies in Oberlin, Ohio, features low-e glaze windows that hold in heat during winter and keep heat out in the summer. 


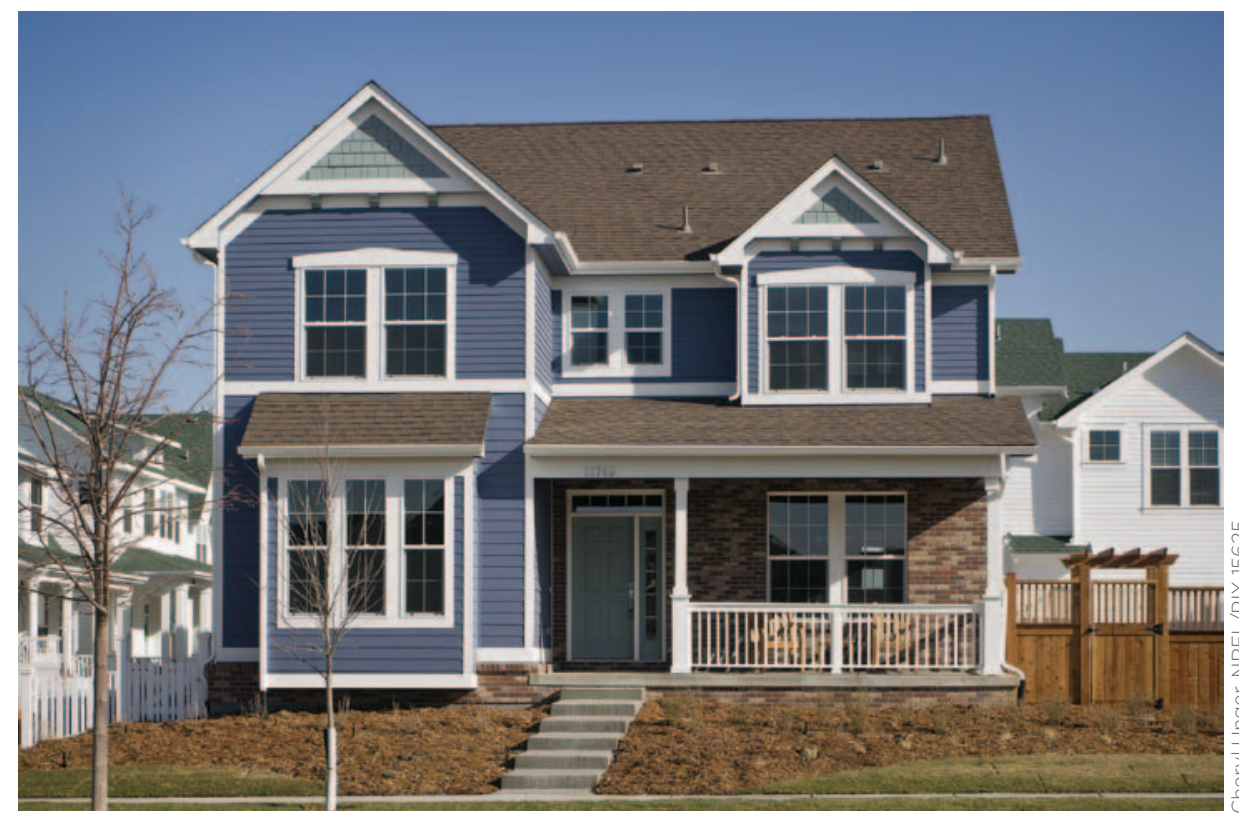

This ENERGY STAR ${ }^{\circledR}$ home in Colorado uses at least 15\% less energy than a typical home built to code and features a solar PV system.

\section{Organizations and Associations \\ Alliance to Save Energy}

Information about energy efficiency, including building green schools and commercial buildings

wWw.ase.org

\section{American Architectural Manufacturers Association}

Includes information and news about building green in its green building section

www.aamanet.org/

general.asp?sect=1\&id=315

\section{American Council for an Energy Efficient Economy (ACEEE)}

ACEEE has energy efficiency information for both residential www.aceee.org/Consumer/index.htm and commercial buildings www.aceee.org/buildings/ commercial.htm
American Society of Heating, Refrigerating, and Air-Conditioning Engineers

Information about the latest standards for green buildings

www.ashrae.org

\section{American Solar Energy Society}

Information about using solar for green homes

wWw.ases.org

\section{American Wind Energy Association}

Information on wind energy

projects and technology and

policy development

wWw.awea.org

\section{BuildingGreen.com}

Information about green buildings including books on green products www.buildinggreen.com/

\section{Build It Green}

A nonprofit organization dedicated to energy and resource efficient building in California

www.builditgreen.org

\section{Common Fire Foundation}

A nonprofit organization dedicated to teaching others about green building www.commonfire.org/

\section{Cool Roof Rating Council}

Provides an independent rating system for cool roofs used in green buildings www.coolroofs.org

\section{Energy \& Environmental Building Alliance \\ Offers educational classes and information about green buildings www.eeba.org}

\section{Green Building Resource Center}

Free design advice and information about environmentally friendly products and strategies www.globalgreen.org/gbrc

\section{Green Concepts}

Information about environmentally friendly products and green building wWw.greenconcepts.com

\section{Geothermal Energy Association}

Geothermal resource maps and listing of U.S. geothermal plants by state www.geo-energy.org

\section{Home Ventilating Institute}

Information about ventilation systems for home and businesses www.hvi.org

\section{Indoor Air Quality Association}

A nonprofit organization dedicated to improving indoor air quality www.iaqa.org

\section{National Association of Home Builders (NAHB)}

NAHB Green www.nahbgreen.org and the NAHB Research Center www.nahbrc.org provide resources and information to builders about green homes and products. 


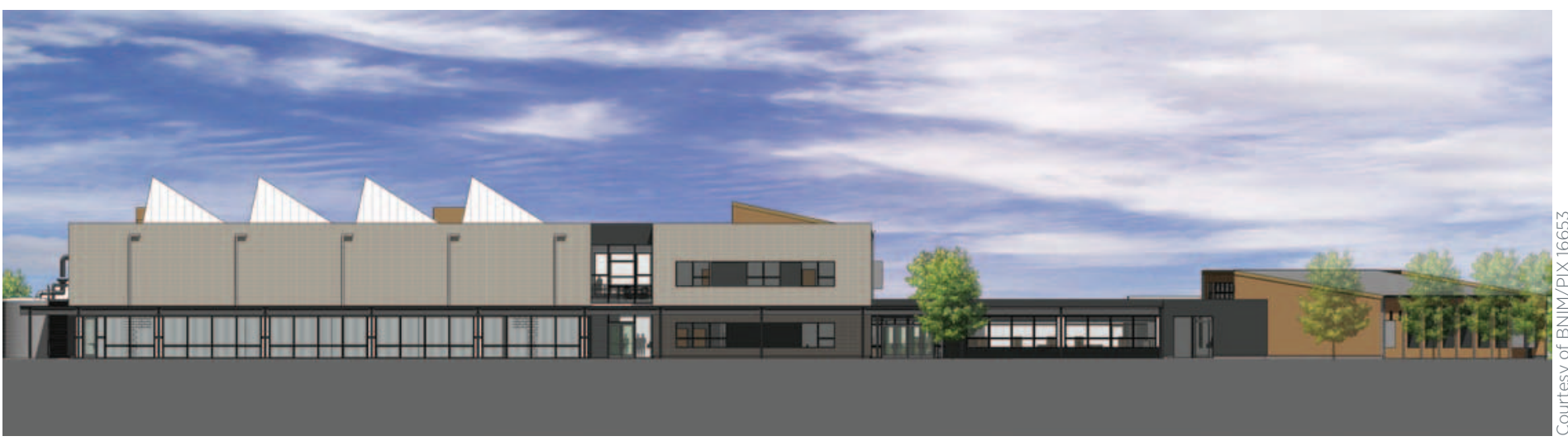

The new high school in Greensburg, Kansas, is being built using green strategies such as the use of daylighting in the gymnasium to offset artificial lighting loads.

\section{National Resources Defense Council}

Information for builders about how green homes and commercial buildings can boost the bottom line www.nrdc.org/buildinggreen

\section{National Roofing Contractors Association}

Trade association for the roofing industry that has an online "Energy Wise" roof calculator wWw.nrca.net

\section{New Homes Directory}

A national directory of new green homes and communities www.newhomesdirectory.com/green

\section{National Recycling Coalition, Inc.}

Provides waste reduction information for builders

www.nrc-recycle.org

\section{North American Insulation Manufacturers Association}

Information about various types of insulation, including fiber glass, rock wool, and slag wool insulation products. Builders can search for green products wWw.naima.org

\section{Sustainable Buildings Alliance}

International organization dedicated to sustainable development and green buildings

www.sballiance.org/

\section{Sustainable Buildings Industry Council}

Provides educational classes and resources for passive solar design www.SB/Council.org

\section{U.S. Green Building Council (USGBC)}

USGBC has information about green commercial and residential buildings as well as the LEED (Leadership in Energy and Environmental Design) rating system for commercial buildings www.usgbc.org/. They also have a blog about green buildings http://blog.epa.gov/blog/category/ greenbuilding
U.S. DEPARTMENT OF ENERGY

\section{Energy Efficiency \& Renewable Energy}

EERE Information Center
1-877-EERE-INF (1-877-337-3463)
eere.energy.gov/informationcenter

Prepared by the National Renewable Energy Laboratory (NREL), a national laboratory of the U.S. Department of Energy, Office of Energy Efficiency and Renewable Energy; NREL is operated by the Alliance for Sustainable Energy, LLC.

This document is one in a series of documents outlining the options for and benefits of rebuilding green after a disaster.

The series draws on lessons learned by teams from the U.S. Department of Energy and its National Renewable Energy Laboratory as they helped the townspeople of Greensburg, Kansas, rebuild green after a devastating tornado. To see the other documents in this series, visit www. buildings.energy.gov/greensburg/.

DOE/GO-102009-2769 • October 2009

Printed with a renewable-source ink on paper containing at least 50\% wastepaper, including $10 \%$ post consumer waste. 